\title{
Nollywood Accounting and Financial Performance: Evidence From Nigerian Cinemas
}

\author{
Olaoluwa Elsie Umukoro ${ }^{1}$, Damilola Felix Eluyela ${ }^{2}$, Emmanuel Ozordi ${ }^{1}$, Ofe Iwiyisi Inua ${ }^{3} \&$ Sheriff Babajide \\ Balogun $^{3}$ \\ ${ }^{1}$ Department of Accounting, Covenant University, Ota, Ogun State, Nigeria \\ ${ }^{2}$ Department of Accounting and Finance, Landmark University, Omu Aran, Nigeria \\ ${ }^{3}$ Department of Financial Studies, National Open University, Nigeria \\ Correspondence: Damilola Felix Eluyela, Department of Accounting and Finance, Landmark University, Omu Aran, \\ Nigeria.
}

Received: September 4, 2019

Accepted: November 29, 2019

Online Published: March 17, 2020

doi:10.5430/ijfr.v11n2p271

URL: https://doi.org/10.5430/ijfr.v11n2p271

\begin{abstract}
The main aim of this study is to discover what influences the financial performance of a given Nollywood film in Nigerian cinemas. We hypothesize that social media, filmmakers and friends influences financial performance of Nollywood films in Nigeria. In order to achieve this objective, we adopted survey research design methodology via the use of google forms to generate 530 copies of questionnaire between November 2018 and January 2019. Using resource dependency theory, we find out that social media, filmmakers and friends are major determinant of Nollywood financial performance in Nigeria. We recommend that filmmakers should embark on more social media campaigns and adverts in order to generate more revenue and profit for their films.
\end{abstract}

Keywords: films, Nollywood, resource dependency theory, performance

\section{Introduction}

The Nigerian film industry has grown exceedingly in recent times. The earliest feature film that was shot in Nigeria was in the year 1926 and it was a double honour as at that time because it was also the first time Nigerians were given speaking roles in a movie. The movie was titled 'Palava' and it was owned by Geoffrey Barka. The movie industry soon advanced to coloured movies as Sam Zebba directed 'Fincho' using the coloured feature. The Indigenization policy also aided the fast growth of the Nigerian movie industry as 300 film theatres owned by foreigners had to be handed over to Nigerians and this made more Nigerians more interested in film business. The period of plenty marked by the high revenue accruing tot the country due to sales of oil produce, made it possible for Nigerians to have extra cash to spend on investing in technology such as televisions and VHS, recreational activities and social moments, hence this aided content growth and birth more television programmes and stations as the years went by (Steedman, 2018).

The production of Nigerian films began a while back where the likes of Late Hubert Ogunde, Late Duro Ladipo, Late Pa Afolayan, Chief Amata, Lere Paimo etc entertained and educated people through the use of stage performances and cinematic efforts. Several years' later series like Cock crow at dawn (early 1980s), Icheoku (80s), Ripples (1988-1993), Mirror In The Sun (1984-1986), Koto Orun (90s), Things fall apart (1987), Check mates (1991-1994), Village headmaster (1968-1988), Agbara Nla/Ultimate Power (1992/1994), Tales by moonlight (1984-unknown), Basi and Company (1986-1990), I Need to Know (1997-2002), Palace (1998), New Masquerade (the mid-80s mid-90s) and Fuji House of Commotion (200s) hit the air waves Ayomide, (2018). The first blockbuster television series was produced from the stable of Wale Adenuga Productions, about sixty-one thousand naira was made in the year 2015. A Yourba film 'Mosebolaton' made a little above a hundred thousand in the year 2016. A very notable and remarkable film that actually heralded the advent of Nollywood was 'living in bondage' Kenneth Okonkwo played lead role, the film was written by Kenneth Nnebue, directed by Chris Obirapu and produced by Kenneth Nnebue and Okey Ogunjiofor. This film was produced in VHS and gained national approval and commendation, it is worthy of note to state here that 27 years after the release of the film, a sequel is about to be birth as Ramsey Nuoah, one of Nigeria's award winning actor has secured the rights to make a sequel which would be titled 'Living in 
bondage (Breaking Free) and this would serve as his directorial debut, Orubo, (2018).

The popularity gained by certain productions in Nigeria such as 'Living in Bondage' encouraged more investors in Nollywood and gradually more films flooded the market, countries like Ghana, South-Africa, Caribbean and even developed countries became interested in the films produced in this part of the world and this came with heavy criticism and this had helped shaped Nollywood as Nigerian films now air on international platforms such as Lion heart, Taxi driver, Arbitration, Falling, fifty and wedding party. Nollywood is currently the third largest film industry in the world and employs a major percentage of her population Ayengho, (2012). Nollywood is said to produce the highest number of films in the world and the third in rank, in terms of revenue generation and has made a whopping 500 million dollars since inception Banziger, (2016) and Orubo, (2018).

Civilization and the quest to earn a living has necessitated the need to make profits out of every activity of life. Film making was formerly believed to be strictly a not for profit organisation as it was formerly not taken as a profession that anyone could earn a meaningful living from. Various movie producers, writers and directors have emulated the whites through learning the ropes of what it takes to make a good movie and they have brought the knowledge acquired to Nigeria and produced many films that have either fallen short of international standards due to lack of sufficient funds to employ equipment that would help birth their vision to life.

The use of loans and sourcing of funds from investors who are interested in the returns that would accrue to them if they throw in their fund into any movie project became the only options available to determined film makers. The problem of piracy and distribution has been a re occurring problems for all film makers and even though in recent times, various distribution channels are available, piracy is still a hard knock to crack for film makers, hence most of them boycott the use of dvds and cds in selling their movies as cinema films are a lot harder to pirate if certain loopholes are tightened.

However, despite the availability of the cinema bail out option, it has been discovered that that certain not all films that make it to the cinema actually earn a lot of revenue, some movies never get to sell out a single cinema hall, while other get to run for weeks and continue to sell out. Examples of such films include King of boys, The ghost and the tout, Wedding party, Chief daddy, Alakada reloaded, Merry Men etc. The purpose of this research is to empirically discover if certain observed variables have a role to play in the financial performance of a given nollywood film.

Observation has revealed that certain characteristics are responsible for the financial performance of Nollywood movies in the cinema and they include the extensive use of social media, television adverts, radio adverts and bill board adverts. Others believe the director, actors and producers have more influence on the number of people that troupe in to watch a movie, thereby increasing revenue. Various cinema films have come and gone, some made box office hits and generated a lot of revenues and remained in the cinema for months because of the continuous influx of audience, movies such as Figurine, October 1, 30 days in Atlanta, King of boys, Chief Daddy, Wedding Party, Ghost and the Tout, Alakada Reloaded, Dry etc. While some barely had up to three weeks run in the cinemas due to lack of viewers even though they had amazing story lines and known casts. It is against this backdrop that this research work intends to empirically discover what influences the financial performance of a given Nollywood film in Nigerian cinemas.

\section{Background}

\subsection{Social Media and Financial Performance}

The use of social media has gone beyond the normal concept of just posting pictures, socialising and sending friend requests. In recent times, social media has become a virtual office, where money is made for certain individuals who understand how to utilize the medium. Research has revealed that people younger than 50 make use of social media more than those above 50, Brenner \& Duggan, (2013).

The table below shows the result of the survey conducted. 


\begin{tabular}{|c|c|c|}
\hline \multirow{2}{*}{\multicolumn{2}{|c|}{ All internet users $(n=1,802)$}} & \multirow{3}{*}{$\begin{array}{c}\begin{array}{c}\text { Use Social } \\
\text { Networking Sites }\end{array} \\
6796 \\
62 \\
\end{array}$} \\
\hline & & \\
\hline $\mathrm{a}$ & Men $(n=846)$ & \\
\hline $\mathrm{b}$ & Women $(n=956)$ & $71^{2}$ \\
\hline \multicolumn{3}{|c|}{ Race/ethnicity } \\
\hline a & White, Non-Hispanic $(n=1,332)$ & 65 \\
\hline $\mathrm{b}$ & Black, Non-Hispanic $(n=178)$ & 68 \\
\hline c & Hispanic $(n=154)$ & 72 \\
\hline \multicolumn{3}{|c|}{ Age } \\
\hline a & $18-29(n=318)$ & $83^{\text {bcd }}$ \\
\hline $\mathrm{b}$ & $30-49(n=532)$ & $77^{-6}$ \\
\hline c & $50-64(n=551)$ & $52^{\mathrm{C}}$ \\
\hline d & $65+(n=368)$ & 32 \\
\hline \multicolumn{3}{|c|}{ Education attainment } \\
\hline a & Less than high school/high school grad $(n=549)$ & 66 \\
\hline $\mathrm{b}$ & Some College $(n=519)$ & 69 \\
\hline $\mathrm{c}$ & College $+(n=721)$ & 65 \\
\hline \multicolumn{3}{|c|}{ Household income } \\
\hline a & Less than $\$ 30,000 / y r(n=409)$ & 72 \\
\hline $\mathrm{b}$ & $\$ 30,000-\$ 49,999(n=330)$ & 65 \\
\hline c & $\$ 50,000-\$ 74,999(n=283)$ & 66 \\
\hline d & $\$ 75,000+(n=504)$ & 66 \\
\hline \multicolumn{3}{|c|}{ Urbanity } \\
\hline a & Urban $(n=561)$ & $70^{c}$ \\
\hline $\mathrm{b}$ & Suburban ( $n=905$ ) & 67 \\
\hline $\mathrm{c}$ & Rural (n=336) & 61 \\
\hline
\end{tabular}

Source: Rainie, Smith, Schlozman, Brady, \& Verba (2012)

Various social media platforms have emanated such as Hi5, Facebook, Twitter, Instagram, MySpace, LinkedIn, whatsapp, BBM etc. These various platforms are major source of advertising for most companies, financial institutions, enterprises, political parties, clubs and societies etc and have at one time or the other been used for various forms of advertising. It is believed that the extensive use of social media can help any government win elections and help any brand that does not underestimate the power of social media become a major force to be associated with, (Kerrigan, 2010; Williams, 2017). The film industry is not lacking behind in the running of adverts using either billboards, twitter or Instagram, most movies produced in this present day is placed on this platform not just for awareness purposes but for the sole aim of making profits through the sales of movies tickets.

Okorie, (2019) is of the opinion that the use of social media, television and radio adverts, word of mouth strengthens the financial performance of a given nollywood cinema film. Tedela, (2018) is also of the opinion that although the use of online digital platforms are also very important but the use of television adverts increases the awareness of a particular film and most audience are more likely to go out and watch a movie that has been advertised on their television screens. Williams (2017) believes the holistic use of all social media platforms would result into more audience which automatically translates to more money for the producers of the movie. Fakorede, (2019) is of the opinion that Instagram adverts is very vital for any movie to recoup the monies invested in production. Adetutu, (2019) is of the opinion that adverts are very crucial in endearing more viewers to the cinemas to watch a given movie and Instagram adverts takes the lead. Gambo, (2018) on the other hand is of the opinion that other factors, such as release dates, story lines play important roles in making money but the strategic use of marketing is as important as making the movie itself, in his interview he stated that holly wood films are marketed with as much money as they used in birthing the film to life. Kerry, (2018) reveals that apart from all forms of marketing be it billboards, twitter or Instagram, she feels some Nigerians rely on movie critics before giving their hard earned cash to watching any movie, most movie critics make their opinions known on Instagram and some cunny film makers find a way to either cajole them to dance to their tune and this serves as a form of publicity, cos once a known movie reviewer endorses your film via a social media platform, which is most probably Instagram or twitter, there is a high probability that more viewers would be encouraged to watch. Egwenu, (2019) in her interview stated plainly that the importance of a marketing a cinema film cannot be over emphasized and in her opinion Twitter takes the lead as a lot of movie watchers take to Twitter to determine if it is worth paying for. Observation has revealed that a lot of Nollywood cinema films have been advertised on some social media platforms and still not made so much money from movie sales, this research work delves into determining whether social media has any role to play in the financial performance of Nollywood films in Nigerian cinema. Against this backdrop, hypothesis one is stated as follows: 
$\mathrm{H}_{01}$ : There is no significant relationship between social media and financial performance of Nollywood films in the cinema.

\subsection{Filmmakers and Financial Performance}

Filmmakers comprises of humans who bring in their skills to ensure a movie is created. They include writers, actors, producers, directors, production managers and crew members, of all the hands that are involved in making a movie, the actors, producers and directors are the most popular of the gang, hardly would you find a viewer who is concerned about who the art director, or the sound engineer for a given movie is. Umukoro et al (2019) concluded that board expertise is a required skill for sustainability reporting. Similarly, Egwenu, (2019) stated that the success of each cinema movie is heavily dependent on the social media marketing strategy and the actors involved, as viewers are more likely to go and see a movie because of the actor than the producer or director, in her opinion the more popular the actor, the more money likely to be generated. Observation has personally buttressed this point as movies that have made box office hits such as King of boys, Wedding Party, 30 days in Atlanta, Merry Men and Chief Daddy all had one thing in common and this is simply the use of popular actors with massive followers on Instagram and Twitter. Cinemapointer, (2019) revealed in their interview, that Instagram adverts and posts aid ticket sales a lot, as most Instagram users are already tuned up for visual content and are more likely to engage with and are more enthusiastic about movie content.

Gambo, (2018), Egwenu, (2019), Cinemapointer, (2019), Fakorede, (2019), Kerry, (2019) \& Okorie (2019) are of the opinion that only actors play an important role in determining whether or not a cinema film would be a box office hit or not, as audience care very little about who the producer or director is except the producer or director is a known celebrity. Actors and celebrities have proven to be a big factor in Nigeria and this is not only by starring in movies but also by making appearances at various cinemas and malls to sell tickets and take pictures with their fans, although no empirical research has been carried as regards Nollywood, observation has revealed that use of actors and celebrities in a movie and engaging them in cinema visit produces high revenues for films. Some Nigerian movies have made box office hits majorly because of the popularity of the producers and directors, this is majorly because they have either set a standard and viewers expect nothing less for them or they have a huge social media following and supportive fans (Kerrigan, 2010a; Kerry, 2018; Cinemapointer, 2019; Adetutu, 2019). Due to this mixed opinions, second hypothesis is formulated as follows:

$\mathrm{H}_{02}$ : There is no significant relationship between filmmakers and financial performance in the Nigerian Cinema films.

\subsection{Friends and Financial Performance}

Chukwu et al (2019), established that forensic accounting skills are necessary tools required to enhance credibility in financial statements. In the same vein Cinemapointer, (2019), Okorie, (2019), Fakorede, (2019) \& Egwenu, (2019) reveal that Nigerian cinema lovers are more likely to watch a movie a friend recommends, i.e they would most likely be seek their counter parts opinion than watch a movie because a certain individual directed or produced it. It is against this backdrop that this research has decided to empirically verify if truly friends play an important role in determining box office hits in Nigerian cinemas.

$\mathrm{H}_{03}$ : There is no significant relationship between friends and financial performance in the Nollywood cinema films.

\subsection{Theoretical Framework}

We adopted resource dependency theory in this study. The basic argument of resource dependency theory is that organisations depend on resources (Eluyela et al, 2018a; Hillman, Withers, \& Collins, 2009; Oladipo et al, 2019b; Szymaniec \& Austen, 2011; Uwuigbe et al, 2018). These resources originate from the environment of an organisation which include other organisation. Resources are basic of power. Legally independent organisations can depend on each other. This theory is particular important to this study because film makers make use of external factor for funding their film production and depend on other external factors. During the strategic pre-production planning, the film makes ensure all parties brought into play would yield maximum revenue by luring more audiences to buy cinema tickets. This will in turn result into high level of profit for the producing organisation (Eluyela et al, 2019b).

\section{Materials and Methods}

The study adopted a Purposive survey research design (Akintimehin et al, 2019; Oladipo et al, 2019a). It is adopted because the study deals with evaluation of opinions of respondents with regards to the focus of the study. Our respondents were strictly cinema audience in Nigeria as they suit the purpose of the study. Primary data was used as a total of 530 questionnaires was distributed via google forms for period three months' period between November 2018 and January 2019. Regression analysis was conducted to validate all variables. This is in line with (Eluyela et al, 
2019a; Okere et al, 2019; Ozordi et al, 2019; Steedman, 2018). The ethical committee approving this experiment are the authors involved in the research. A pilot test was first conducted among the authors before the actual field test was carried out.

\section{Research Instrument}

The five point Likert scale was modified in developing the questionnaire, slightly agree and slightly disagree was added to the five point Likert scale while undecided was removed. The research instrument comprised of a brief set of demographic questions, including questions on age, gender etc and questions to elicit information on the effect Nollywood accounting has on the financial performance of cinema films in Nigeria. The questions were divided into sections as each objectives generated its different set of questions. Multiple regression analysis using statistical package for social science (S.P.S.S) 20.0 was utilized as the method of data analysis and the models would pass through a regression analysis. The package has a range of statistical techniques for conducting analysis of data that will be useful for this study.

The designed questionnaire was submitted to research experts and other Nollywood professionals and critics for scrutiny and corrections, Statisticians and experts were consulted and the suggestions made were incorporated in the final draft of the instrument to ensure content validity before administering on the respondents a pilot study was also carried out.

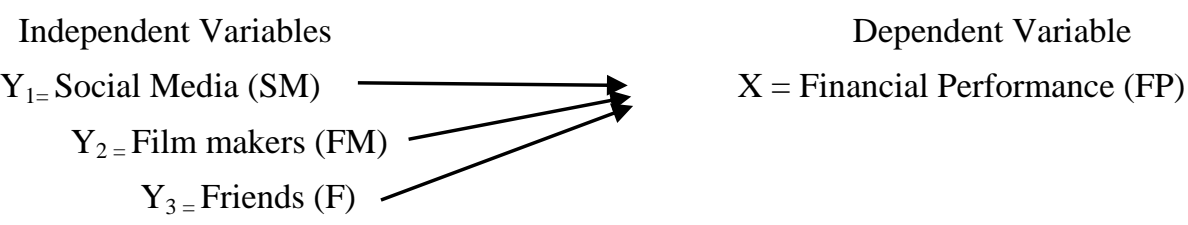

\subsection{Functional Relationship}

The base line model for this study was adapted from the work of Otekunrin et al (2019). This is stated below.

$$
\begin{gathered}
y=\alpha_{0}+\alpha_{1} X_{1}+\alpha_{2} X_{2}+\alpha_{3} X_{3}+\delta_{i t} \\
F P=\alpha_{0}+\alpha_{1} S M_{1}+\alpha_{2} F M_{2}+\alpha_{3} F R_{3}+\delta_{i t}
\end{gathered}
$$

Where FP represent financial performance of cinema films; SM is social media (which include twitter, Instagram, Facebook); FM is film makers and FR is friends (Eluyela et al, 2018b).

\section{Results and Discussion}

In this section, results from 530 responses were analysed and discussed. We also include the hypothesis testing in this section.

Table 1. Model summary

\begin{tabular}{llll}
\hline Model & R & R Square & Adjusted R Square \\
\hline 1 & $.327^{\mathrm{a}}$ & .107 & .099 \\
\hline
\end{tabular}

Source: Authors computation (2019)

Table 2. Anova analysis

\begin{tabular}{lllllll}
\hline ANOVA $^{\text {a }}$ & \multicolumn{1}{l}{} \\
\hline Model & & Sum of Squares & Df & Mean Square & F & Sig. \\
\hline \multirow{2}{*}{1} & Regression & 5.882 & 5 & 1.176 & 12.469 & $.000^{\mathrm{b}}$ \\
\cline { 2 - 7 } & Residual & 48.967 & 519 & .094 & & \\
\cline { 2 - 6 } & Total & 54.850 & 524 & & & \\
\hline \multicolumn{2}{l}{ a. Dependent Variable: Financial Performance } \\
\hline \multicolumn{7}{l}{ b. Predictors: (Constant), Twitter, Instagram, Facebook, Bloggers, Billboards } \\
\hline
\end{tabular}

Source: Authors computation (2019) 
Table 3. Regression table

\begin{tabular}{|c|c|c|c|c|c|c|}
\hline \multirow[t]{2}{*}{ Model } & & \multicolumn{2}{|c|}{ Unstandardized Coefficients } & \multirow{2}{*}{$\begin{array}{l}\text { Standardized Coefficients } \\
\text { Beta }\end{array}$} & \multirow[t]{2}{*}{$\mathrm{t}$} & \multirow[t]{2}{*}{ Sig. } \\
\hline & & $\overline{\mathrm{B}}$ & Std. Error & & & \\
\hline \multirow{6}{*}{1} & (Constant) & 1.338 & .034 & & 39.100 & .000 \\
\hline & Instagram & -.042 & .012 & -.185 & -3.516 & .000 \\
\hline & Billboards & .017 & .014 & .066 & 1.193 & .233 \\
\hline & Bloggers & -.026 & .014 & -.103 & -1.887 & .060 \\
\hline & Facebook & -.004 & .010 & -.020 & -.400 & .689 \\
\hline & Twitter & -.039 & .012 & -.159 & -3.175 & .002 \\
\hline
\end{tabular}

Source: Authors computation (2019)

Hypothesis 1: There is no significant relationship between social media and financial performance of Nollywood films in the cinema.

Decision: Reject Null Hypothesis and accept alternate.

The results from Tables 1-3 show the individual regression of social media platforms. This result reveals that Instagram and Twitter adverts has a significant relationship with financial performance, put simply, the more awareness created using this platform, the more revenue that would accrue to the owners of the film. This is in line with Cinemapointer, (2019), Egwenu, (2019), Okorie, (2019), Adetutu, (2019). Observation has also revealed that most Nollywood cinema films that have made box office hits employed the aggressive use of Instagram adverts and this adverts includes leveraging on their followers and using the Instagram sponsored posts platform. Egwenu, (2019) stated that Twitter is the most engaging social media platform hence adverts and awareness created via this medium would yield massive results, on the other hand Cinemapointer, (2019) stated that Instagram is the most visually engaging platform hence the users of this application constantly look forward to appealing visual content.

When billboard, bloggers and Facebook were regressed, a 0.233, 0.060 and 0.689 significant values were obtained respectively, this revealed that there is no relationship between either the use of bloggers to run adverts, the use of billboard to create awareness for the film and face book adverts on financial performance of Nollywood cinema films and this is in line with Adetutu, (2019), Okorie, (2019). Although, Gambo, (2018) and Kerry, (2019) were of the opinion that all social media marketing increases the chances of more revenue, this empirical evidence does not validate that.

Hypothesis 2: There is no significant relationship between filmmakers and financial performance in the Nigerian Cinema films.

Decision: Accept Alternate hypothesis, reject null hypothesis

Table 4. Model summary

\begin{tabular}{llll}
\hline Model & R & R Square & Adjusted R Square \\
\hline 1 & $.364^{\mathrm{a}}$ & .133 & .128 \\
\hline
\end{tabular}

Source: Authors computation (2019)

Table 5. Anova analysis

\begin{tabular}{lllllll}
\hline ANOVA $^{\mathbf{a}}$ & \multicolumn{1}{l}{} & & & & \\
\hline Model & & Sum of Squares & df & Mean Square & F & Sig. \\
\hline \multirow{2}{*}{1} & Regression & 7.286 & 3 & 2.429 & 26.605 & $.000^{\mathrm{b}}$ \\
\cline { 2 - 7 } & Residual & 47.563 & 521 & .091 & & \\
\cline { 2 - 7 } & Total & 54.850 & 524 & & & \\
\hline
\end{tabular}

a. Dependent Variable: Financial Performance

b. Predictors: (Constant), Directors, Actors, Producers

Source: Authors computation (2019) 
Table 6. Regression table

\begin{tabular}{|c|c|c|c|c|c|c|}
\hline \multirow[t]{2}{*}{ Model } & & \multicolumn{2}{|c|}{ Unstandardized Coefficients } & \multirow{2}{*}{$\begin{array}{l}\text { Standardized Coefficients } \\
\text { Beta }\end{array}$} & \multirow[t]{2}{*}{$\mathrm{t}$} & \multirow[t]{2}{*}{ Sig. } \\
\hline & & B & Std. Error & & & \\
\hline \multirow{4}{*}{1} & (Constant) & 1.383 & .035 & & 40.000 & .000 \\
\hline & Actors & -.055 & .016 & -.165 & -3.469 & .001 \\
\hline & Producers & -.048 & .012 & -.200 & -4.055 & .000 \\
\hline & Directors & -.021 & .013 & -.082 & -1.665 & .097 \\
\hline
\end{tabular}

The Tables 4-6 above show that filmmakers have a 36.4 percent correlation with financial performance. The 63.6 percent difference can be explained by other variables not captured in this model. The relationship reveals a weak positive relationship. The $\mathrm{P}$ value reveals a significant value of 0.000 at $5 \%$ level of significance and this simply means that filmmakers have an effect in determining whether or not a film would earn well or not and this is tandem with Tedela, (2018), Gambo, (2018), Adetutu, (2019), Cinemapointer, (2019) and Kerry, (2019).

The regression of variables that make up the film maker independent variable against the dependent variable (financial performance) reveal that a significant $\mathrm{P}$ value for actors $(0.001)$ and producers $(0.000)$. This simply means actors have a major role to play in determining how much a movie makes at box office, hence the quality of actors should not be over looked and this is in line with Gambo, (2018), Fakorede, (2019), Okorie (2019), Adetutu, (2019) and Egwenu, (2019).

Tedela, (2018), Adetutu, (2019), Fakorede, (2019), Okorie, (2019) and Kerry, (2019) stated that cinema watchers rarely watch any cinema film based on the producer of the movie and this is not in line with this empirical research, in their opinion most cinema audience care less about who produced or directed a particular movie except the producer or director is a popular celebrity and known to churn out top notch productions. Although observations reveal that most Nigerian producers double as actors, hence their fans churn out to support them because of their acting fame and not their 'producing skills', an example of a producer in Nigeria, that doubles as an actor and has made box office hits severally is Toyin Abraham. The value obtained when we measured the effect directors have on the financial performance of nollywood films reveal an insignificant value (0.097). This simply means that cinema audience in Nigeria pay less attention to the director figure and this does not encourage or discourage them from purchasing their movie tickets. This is in line with Okorie, (2019), Fakorede, (2019) and Egwenu, (2019).

Adetutu, (2019) and Kerry, (2019) believe that directors actually influence the number of humans that watch a particular film, but this empirical result has revealed that directors alone has no significant relationship with the financial performance of a given firm. Although, collectively the $\mathrm{P}$ value is significant and this means every film maker has a role to play in the financial performance of a given film.

Hypothesis 3. There is no significant relationship between friends and financial performance in the Nollywood cinema films.

Decision: Accept Alternate hypothesis, Reject Null Hypothesis

Table 7. Model summary

\begin{tabular}{llll}
\hline Model & $\mathrm{R}$ & R Square & Adjusted R Square \\
\hline 1 & $.277^{\mathrm{a}}$ & .077 & .075 \\
\hline
\end{tabular}

Table 8. Regression table

\begin{tabular}{lllllll}
\hline Model & \multicolumn{2}{l}{ Unstandardized Coefficients } & Standardized Coefficients & \multirow{2}{*}{ S } & \multirow{2}{*}{ Sig. } \\
\cline { 2 - 6 } & B & Std. Error & Beta & & \\
\hline 1 & Constant & 1.254 & .027 & & 46.18 & .000 \\
\cline { 2 - 5 } & Friends & -.082 & .012 & -.277 & -6.56 & .000 \\
\hline
\end{tabular}

Source: Authors computation (2019) 
Table 9. Anova analysis

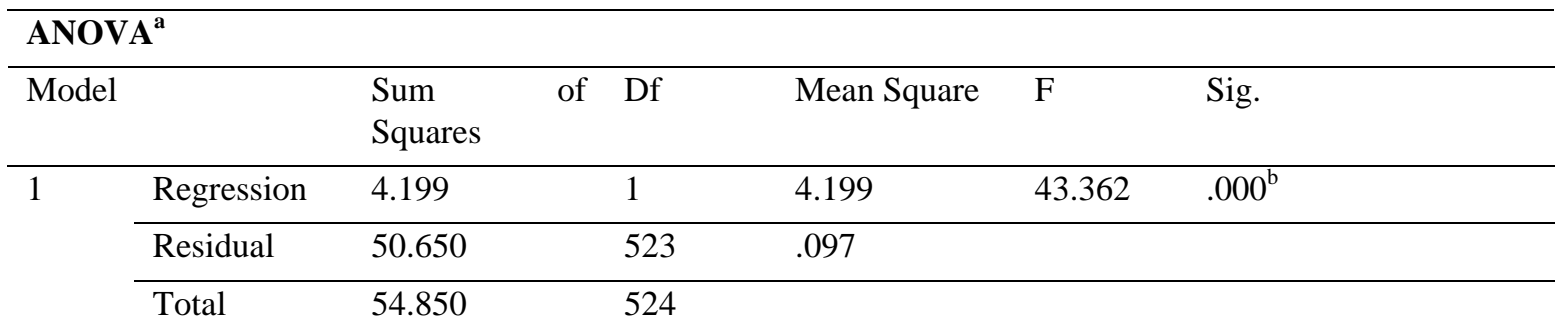

a. Dependent Variable: Financial Performance

b. Predictors: (Constant), Friends

Source: Authors computation (2019)

Table 8 reveals that there the $\mathrm{P}$ value is significant. This simply means that word of mouth persuasion aids audience more to watch Nollywood cinema films and this is in line with Gambo, (2018), Okorie, (2019), Adetutu, (2019), Fakorede, (2019), Kerry, (2019) and Egwenu, (2019).

\section{Conclusion}

This study concluded that social media as a whole has a significant relationship with financial performance and this is in tandem with (Gambo, 2018; Cinemapointer; 2019; Kerry, 2019; Okorie, 2019 and Fakorede 2019). We recommend that filmmakers should embark on more social media campaigns and adverts in order to generate more revenue and profit for their films. This study buttresses various point raised by reviewers and movie experts, who have engaged heavily in the use of adverts to lure more cinema audience in recent times. Researchers and practitioners should endeavour to ply the social media route extensively when seeking solutions on how to maximise revenue and break box office records. Social media variables tested in this study includes adverts on television, Instagram, Twitter, Facebook and the use of Bill boards. This study concludes that not only should adverts on social media be considered as an important factor to determine the financial performance of a given nollywood cinema film.

The empirical findings also increase the body of knowledge by revealing that a significant relationship exists between filmmakers (actors, producers, directors) and the revenue obtained from a given cinema film. This goes further to shed more light on why most nollywood box office films always have popular actors with a large fan base and industry experience, popular producers and directors who are in a class of their own or have earned the trust of film lovers are also not left out (Kerry,2019; Adetutu 2019). Research has shown that most cinema lovers in Nigeria are very quick to watch movies A-list film makers have collaborated on and this films turn in huge profits. Examples include movies such as King of boys, Chief daddy, Bling Lagosians, Set-up, Love is war, 30 days in Atlanta, Lion heart, wedding party etc. These movies all employed the use of social media, most of the lead characters are actors, who know their onions, have a huge fan base and are a delight to watch. Producers and directors of these films are also known for their prowess and excellence. Hence this study empirically validates nollywood strategies.

Friends play important roles in influencing decisions. This study tested the friend variable to determine if Nigeria cinema lovers listen to their friends opinions before buying a movie ticket. The relationship established from this study produced a significant one. The study hereby concludes that word of mouth also helps increase cinema revenue in Nigeria. This is because it is easy to believe your friend's opinion than the opinion of a stranger. This result is in tandem with (Gambo, 2018; Fakorede 2019).

However, there was some inherent limitation faced during the planning and data gathering stage of the study. These are: availability of Nollywood data (most especially financial performance), revenue generated from film production. Based on this limitations, we therefore recommend that filmmakers should also make available their production cost, revenue generated from producing a film and all other performance metrics that will allow researchers and public to assess the overall performance of a film. Other limitations include that the study was limited to Nigeria and we only tested a few variables such as filmmakers, social media and friends. Further studies should examine other proxies and also not limit their sample size to cinema films only. Other aspects of the Nigerian film industry should be empirically investigated. 


\section{References}

Adetutu, A. (2019). Everything or Nothing: The Untold Story of 007. A Movie Critic.

Akintimehin, O. O., Eniola, A. A., Alabi, O. J., Eluyela, D. F., Okere, W., \& Ozordi, E. (2019). Social capital and its effect on business performance in the Nigeria informal sector. Heliyon, 5. https://doi.org/10.1016/j.heliyon.2019.e02024

Ayengho, A. (2012). Inside Nollywood: What is Nollywood?. Retrieved from https://www.vanguardngr.com/2012/06/inside-nollywooo-what-is-nollywood

Ayomide, O. T. (2018). 20 greatest Nigerian shows of all time. Retrieved from www.pulse.ng/entertainment/movies/classic-tv-20-greatest-nigerian-shows-of-all time/3gyvx59

Brenner, J., \& Duggan, M. (2013). Social Networking Site Users. The Demographics of Social Media Users - 2012. Retrieved from http://www.pewinternet.org/2013/02/14/social-networking-site-users/

Chukwu, C., Asaolu, T. O., Uwuigbe, O. R., Uwuigbe, U., Umukoro, O. E., Nassar, L., \& Alabi, O. (2019). The impact of basic forensic accounting skills on financial reporting credibility among listed firms in Nigeria. International Conference on Energy and Sustainable Environment, 331, 1-13.

Cinemapointer. (2019). A movie critic on Instagram.

Daniel, O. (2018). Here's All We Know About the Upcoming 'Living in Bondage' Sequel. Retrieved from http://www.konbini.com/ng/entertainment/cinema/heres-all-we-know-about-the-upcoming-living-in-bondage-se quel/

Eluyela, D. F., Adetula, D. T., Obasaju, O. B., Ozordi, E., Akintimehin, O., \& Popoola, O. (2019a). Foreign directors, indigenous directors and dividend payout structure in Nigerian deposit money banks. Banks and Bank System, 14(2), 1-14. https://doi.org/10.21511/bbs.14(2).2019.16

Eluyela, D. F., Akintimehin, O. O., Okere, W., Ozordi, E., Osuma, G. O., Ilogho, S. O., \& Oladipo, O. A. (2018b). Datasets for board meeting frequency and financial performance of Nigerian deposit money banks. Data in Brief. https://doi.org/10.1016/j.dib.2018.06.044

Eluyela, D. F., Akintimehin, O. O., Ozordi, E., Oladipo, O. A., Ilogho, S. O., \& Okere, W. (2018a). Board meeting frequency and firm performance: examining the nexus in Nigerian deposit money banks. Heliyon, $4,850$. https://doi.org/10.1016/j.heliyon.2018

Eluyela, D. F., Olajide, D., Tolase, O. A., Okere, W., Ogabi, M., \& Kafidipe, A. (2019b). Impact of Gender Dichotomy on Dividend Payout Policy in Listed Nigerian Financial Services Firm. Cogent Business and Management, 6, 1-10. https://doi.org/10.1080/23311975.2019.1687270

Fakorede, M. (2019). The secret of CEO Addition. Retrieved from https://ng.linkedin.com/in/modupe-fakorede-a48a66131

Gambo, F. (2018). Meet Fiyin Gambo who wants to change the status quo in Nollywood. Retrieved from https://youthcentral.ng/2018/10/08/meet-fiyin-gambo-who-wants-to-change-the-status-quo-in-nollywood/

Hillman, A. J., Withers, M. C., \& Collins, B. J. (2009). Resource dependence theory: A review. Journal of Management, 35(6), 1404-1427. https://doi.org/10.1177/0149206309343469

Kerrigan, F. (2010a). Film Marketing (1st ed.). https://doi.org/10.1016/b978-0-7506-8683-9.10011-0

Kerrigan, F. (2010b). The Origins and Development of the Film Industry. Film Marketing (1st ed.). https://doi.org/10.1016/b978-0-7506-8683-9.10002-x

Kerry, E. (2019). Movie Critic. Retrieved from https://peterkerrypowers.com/tag/esther-popel-shaw/

Okere, W., Eluyela, D. F., Lawal, A. I., Ibidunni, O., Eseyin, O., Popoola, O., \& Awe, T. (2019). Foreign Expatriates on Board and Financial Performance: A Study of Listed Deposit Money Banks in Nigeria. The Journal of Social Science Research, 5(2), 418-423. https://doi.org/10.32861/jssr.52.418.423

Okorie, D. (2019). Multi Choice Talent Factory. Retrieved from https://multichoicetalentfacory.com/user/9952

Oladipo, O. A., Fakile, A. S., Ajayi, S. A., \& Eluyela, D. F. (2019a). Budgeting and budgetary control in the agricultural sector: Critical elements in enhancing economic growth in Nigeria. Proceedings of the 33 rd International Business Information Management Association Conference: Education Excellence and Innovation Management through Vision 2020 (pp. 433-446). 
Oladipo, O. A., Iyoha, O. F., Fakile, A. S., Asaleye, A. J., \& Eluyela, D. F. (2019b). Tax revenue and agricultural performance: evidence from Nigeria. Problems and Perspectives in Management, 17(3), 342-349. http://doi.org/10.21511/ppm.17(3).2019.27

Otekunrin, A. O., Nwanji, T. I., Agba, D. Z., Olowookere, J. K., Fakile, S. A., Ajayi, S. A., ... \& Oladiran, T. (2018). Outsourcing of accounting services and strategic cost management method: (A case study of Dangote flour PLC and Doyin Investment Nig. LTD). Proceedings of the 32nd International Business Information Management Association Conference (pp. 8452-8465).

Ozordi, E., Adetula, D. T., Eluyela, D. F., Aina, A., \& Ogabi, M. (2019). Corporate dynamism and cash holding decision in listed manufacturing firms in Nigeria. Problems and Perspectives in Management, 17(4), 1-12, http://doi.org/10.21511/ppm.17(4).2019.01

Rainie, L., Smith, A., Schlozman, K. L., Brady, H., \& Verba, S. (2012). Social Media and Political Engagement. Pew Research Center's Internet \& American Life Project, 1-13.

Steedman, R. (2018, March). Nairobi-based middle class filmmakers and the production and circulation of transnational cinema. Poetics, 0-1. https://doi.org/10.1016/j.poetic.2018.11.002

Szymaniec, K., \& Austen, A. (2011). Resource dependence theory in public management. University of Economics in Katowice Resource, (Penc 1995), 77-83.

Tope, T. (2018). Actor, Producer. Retrieved from https://en.wikipedia.org/wiki/Cinema_of_Nigeria

Umukoro, E. O., Uwuigbe, O. R., Uwuigbe, U., Adegboye, A., Ajetunmobi, O., \& Nwaze, C. (2019). Board expertise and sustainability reporting in listed banks in Nigeria. International Conference on Energy and Sustainable Environment, 331, 1-10.

Uwuigbe, U., Eluyela, D. F., Uwuigbe, O. R., Obakpro, T., \& Falola, I. (2018). Corporate governance and quality of financial statements: a study of listed Nigerian banks. Banks and Bank System, 13(3), 12-23. https://doi.org/10.21511/bbs.13(3).2018.02 